OPEN ACCESS

Citation: Collesano G., Fiorello A., Pasta S. (2021) Strelitzia nicolaii Regel \& Körn. (Strelitziaceae), a casual alien plant new to Northern Hemisphere. Webbia. Journal of Plant Taxonomy and Geography 76(1): 135-140. doi: 10.36253/jopt-10183

Received: November 20, 2020

Accepted: December 24, 2020

Published: April 27, 2021

Copyright: @ 2021 Collesano G., Fiorello A., Pasta S. This is an open access, peer-reviewed article published by Firenze University Press (http://www. fupress.com/webbia) and distributed under the terms of the Creative Commons Attribution License, which permits unrestricted use, distribution, and reproduction in any medium, provided the original author and source are credited.

Data Availability Statement: All relevant data are within the paper and its Supporting Information files.

Competing Interests: The Author(s) declare(s) no conflict of interest.

Editor: Riccardo M. Baldini

ORCID

SP: https://orcid.org/0000-0003-32659072

\section{Strelitzia nicolaii Regel \& Körn. (Strelitziaceae), a casual alien plant new to Northern Hemisphere}

\author{
Giuseppe Collesano ${ }^{1}$, Antonina Fiorello ${ }^{2}$, Salvatore Pasta ${ }^{3, *}$ \\ ${ }^{1}$ Regione Siciliana, Viale Regione Siciliana 33, Palermo, Italy \\ ${ }^{2}$ Bioparco di Sicilia, Via Vespucci 420, Carini, Italy \\ ${ }^{3}$ Consiglio Nazionale delle Ricerche, Istituto di Bioscienze e BioRisorse, Corso Calatafimi \\ 414, Palermo, Italy \\ ${ }^{\star}$ Corresponding author. Email: salvatore.pasta@ibbr.cnr.it
}

\begin{abstract}
The ongoing naturalization of the blue giant paradise bird tree, Strelitzia nicolaii, is here reported for the first time for NW Sicily (Italy). Native to SE Africa, this ornamental plant was locally introduced around mid XIX century. During last two decades the first cases of pollination and dispersal have been recorded, and within last 10 years several individuals were able to establish in abandoned Citrus orchards or in private gardens subject to moderate soil management.
\end{abstract}

Keywords: subtropical ornamental plants, Mediterranean, naturalization, urban areas, dispersal, pollination.

\section{INTRODUCTION}

Sicily is home of around 400 fully naturalized or causal alien plants (Galasso et al., 2018). During last decades, their number experienced a dramatic increase. Additionally, the island often represents the first or the only Italian - or even European - region where the naturalization of many tropical and subtropical woody plants occurred (e.g. Raimondo and Fici 1991; Villari and Zaccone 1999; Raimondo and Domina 2007; Pasta et al. 2012, 2014, 2016, 2017; Badalamenti and La Mantia 2018).

Although the International Plant Names Index (IPNI) lists as much as 34 binomial epithets referred to the genus Strelitzia, nowadays just five taxa are recognized at species rank (Argent 2011; Cron et al. 2012; Baijnath and McCracken 2019). Among them, Strelitzia alba (L. f.) Skeels, S. caudata R.A. Dye and S. nicolaii Regel \& Körn. share the same caulescent/tree-like habit, reaching heights of up to $15 \mathrm{~m}$ (Moore and Hyypio 1970). These three species may be distinguished by petal color (white in $S$. alba, blue in the other two), inflorescence structure (compound with 2-5 spathes in S. nicolaii, simple in the other two) and ecology/distribution range (Wright 1913; Dyer 1945; van der Venter et al. 1975; Goldblatt and Manning 2000; Archer 2003). 
This last species, the one concerned in the present paper, was dedicated by Regel and Körnickie (1858) to Nikolai Nikolaevic, mentor of the Russian Imperial Society of Horticulture of Saint Petersburg. As already pointed out by Speciale and Domina (2016) and according to art. 60.8 of the Shenzen Code (Turland et al. 2018), the correct specific epithet for this species is 'nicolaii' (or 'nikolaii'), and not 'nicolai', as originally (mis)spelled in the protologue and currently reported on many papers concerning the genus Strelitzia (e.g., Cron et al. 2012). In fact, the whole protologue was written in German and the authors did not explicitly adopt the latinized form of the granduke's name.

Within its original distribution range, S. nicolaii prefers rich and moist soils with good drainage in full sun to part shade. Its native habitat are the evergreen coastal forests and thicket communities of the coastal dune environments of eastern South Africa, S Mozambique, E Botswana, KwaZulu-Natal and E Zimbabwe. During last years, the so-called giant blue bird of paradise has been recorded as fully naturalized in New South Wales in Australia (Duretto et al. 2017). It was not possible to confirm a record (https://en.wikipedia. org/wiki/Strelitzia_nicolai) on its naturalization near Veracruz, eastern Mexico. As far as we know, up to now the species only occurs there under cultivation (P. Díaz Jiménez, pers. comm.).

The first report of cultivation of S. nicolaii in Italy dates back to the first half of the XIX century (Manetti 1845; Tenore 1845). The plant was for long time erroneously reported by many European scholars with the misused binomial S. augusta, although the true S. augusta

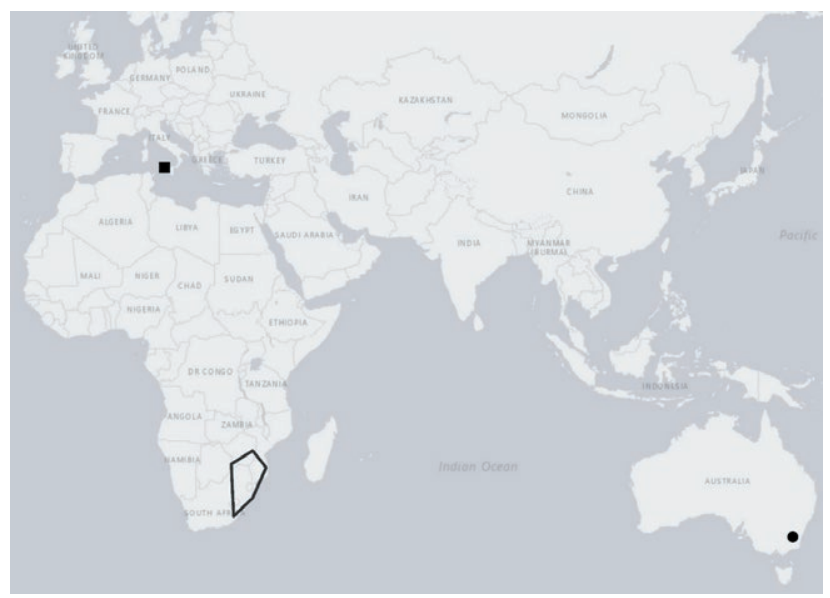

Figure 1. Information on the current distribution of Strelitzia nicolaii. Empty closed line: original distribution range in SE Africa; full dot: naturalization site in SE Australia; full square: location of the nuclei of NW Sicily (Italy) mentioned in this study.
Thunb. is an illegitimate synonym of $S$. alba (Archer, 2003). As for Sicily, Ostinelli (1910) states that 'S. augusta' was already cultivated in Palermo around 1865, and in 1884 it grew in the Botanical Garden of Palermo (Todaro 1885). However, most of - if not all - the previous records of $S$. augusta and all the available specimens of tree-like Strelitzia observed and studied in Sicily belong to S. nicolaii (Speciale and Domina 2016). Due to its highly appreciated ornamental value, shortly after its introduction in Sicily S. nicolaii was widely diffused in local public and private gardens, where some phenological observations were reported by Buscalioni and Trinchieri (1906).

Here we provide some details on the first case of naturalization of $S$. nicolaii for Europe, the Mediterranean area and the whole northern hemisphere.

\section{RESULTS AND DISCUSSION}

The first naturalized individuals of $S$. nicolaii were observed in three different sites (Figure 1). The plants of the first two sites grow in two private gardens close one another located in the plain of Palermo. Both were part of a wide Citrus orchard named 'Fondo Anfossi', almost destroyed due to urban sprawl in the 1960s. A parcel (coordinates: $38^{\circ} 10^{\prime} 47^{\prime \prime} \mathrm{N}, 13^{\circ} 19^{\prime} 36^{\prime \prime} \mathrm{E}, 33 \mathrm{~m}$ a.s.l.) was still cultivated until 1990s, when the previous intensive agricultural practices (application of fertilizer and pesticides, annual soil tilling by means of a motor hoe) have ceased. Since then, weed eradication is only done by means of a grass trimmer and instead of massive summer irrigation, some water supply is provided to the plant by means of an automatized system. After the death of most of the Citrus trees, many other fruit trees and/or ornamental plants have been introduced, such as Annona cherimolia Mill., Araujia sericifera Brot., Asparagus setaceus (Kunth) Jessop, Cycas revoluta Thunb., Dolichandra unguis-cati (L.) L.G. Lohmann, Lantana camara L., Melia azedarach L., Parthenocissus spp., Phoenix canariensis Chabaud, Pittosporum tobira (Thunb.) W.T. Aiton, Robinia pseudoacacia L., Solanum pseudocapsicum L., Solanum torvum Swartz, Trachycarpus fortunei (Hook.) H.Wendl., Washingtonia spp. and Wisteria sinensis (Sims) Sweet, and subsequently many of these species escaped from cultivation. As for S. nicolaii, it was introduced in the garden in 1989; the first ripen fruits (Figure 2) were observed in 2005, and the first seedlings started to grow around $30 \mathrm{~m}$ far from the nearest mother plants just one year after, 2006. Currently four new plants have been observed, i.e. 3 reproductive adults born between 2009 and 2010 and one young 


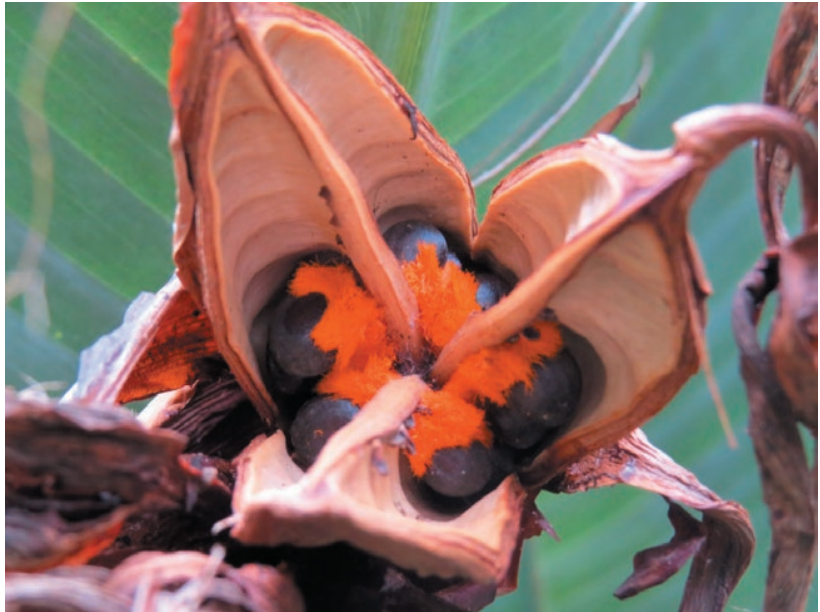

Figure 2. Open fruit of S. nicolaii (photo credit: G. Collesano).

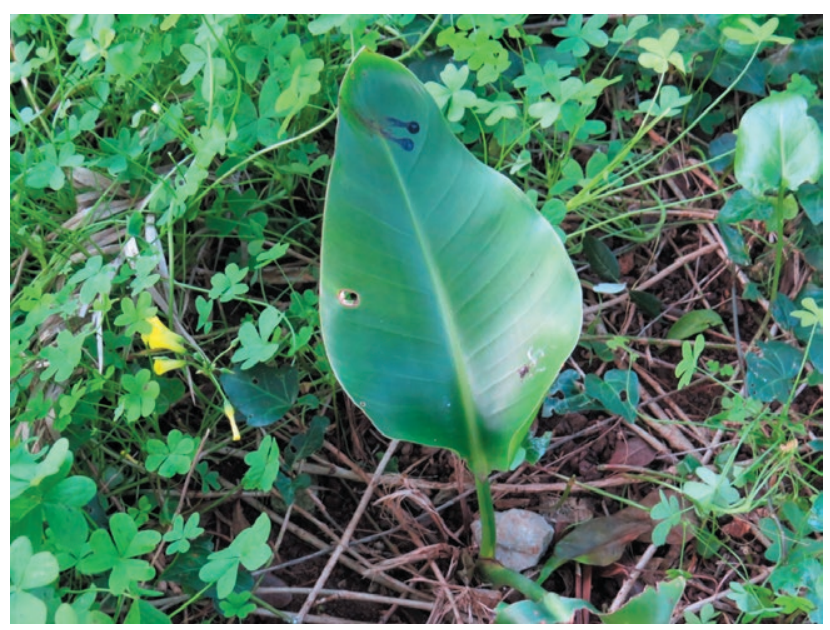

Figure 3. Young plant of S. nicolaii born in a private garden in the Plain of Palermo (photo credit: G. Collesano).

plant born in 2014 (Figure 3), located some 15-20 m far from them. Another single plantlet, probably three years old, growing in an abandoned orchard some 300 $\mathrm{m}$ apart from the first nucleus (coordinates: $38^{\circ} 10^{\prime} 15^{\prime \prime} \mathrm{N}$, $13^{\circ} 19^{\prime} 44^{\prime \prime} \mathrm{E}$ ), has been observed in early April 2019.

No detailed data are available on the spread of the casual plants forming the third nucleus, located within the "Bioparco di Sicilia" (Carini, Palermo province, coordinates: $38^{\circ} 10^{\prime} 04^{\prime \prime} \mathrm{N}, 13^{\circ} 10^{\prime} 38^{\prime \prime} \mathrm{E}$ ), a large private park (about $60,000 \mathrm{~m}^{2}$ ) including a zoological garden and several exhibitions promoting nature conservation and environmental education. Here naturalization processes have started less than 10 years ago. The first 50 individuals of $S$. nicolaii were introduced in the 'dinosaur area' at the same time the park was founded (1998),

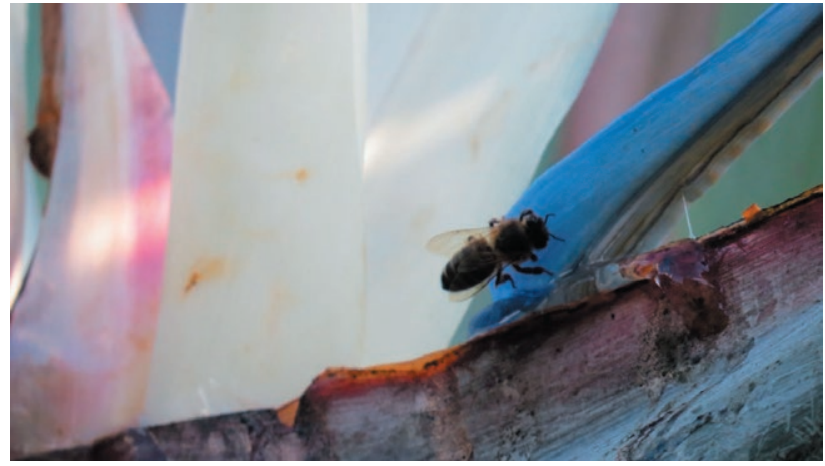

Figure 4. Bee visiting the inflorescence of S. nicolaii (photo credit: G. Collesano).

and subsequently more blue giant paradise bird trees have been planted in the other sectors of the park. Most of them started to flower around 2011-2012, and the first evidences of seed dispersal, mostly concentrated along the paths of the zoo, were noticed around 2014. Considering that numerous isolated seedlings and saplings currently grow some dozens meters far from the adult ones, it sounds highly probable that they represent the offspring of reproductive individuals dispersed by local birds and established during last 5 years. Surprisingly, some of local individuals of $S$. nicolaii have recently been predated by the alien palm weevil, Rhynchophorus ferrugineus (Olivier 1790) (Fiorello et al. 2015).

$S$. nicolaii produces very low amounts of viable seeds through self-pollination (Yamburov et al., 2016), while subtropical frugivorous passerine perching birds (Cronk and Ojeda 2008), attracted by its sugar-rich nectar and the intense blue color of the petals, play a major role in their pollination. Sunbirds are known to pollinate the blue giant paradise bird trees (Frost and Frost, 1981): they have been observed sitting on the portion of the blue petals enclosing the anthers in contact with the sticky pollen (Nichols 2007). In order to perform sexual reproduction in the Mediterranean biome, S. nicolaii must have managed to overcome the lack of native pollinators. Under local conditions, the species is in bloom all the year, with a peak activity during spring and summer. Due to the abundant production of sweet nectar, its inflorescence attracts bees (Figure 4) and probably also other insects like daily or nocturnal moths, and even lizards.

As S. nicolaii may flower during winter, like loquat (Merino and Nogueiras 2003), it may represent a key source of nectar for the few active Hymenopterans (namely bumblebees), and small birds (Cecere et al. 2010; Da Silva et al. 2014). Throughout the area of the municipality of Palermo, whose bird fauna is still quite 
rich (Lo Valvo et al. 1985), the flowers of many ornamental and cultivated plants such as Aloe ssp. and Eriobotrya japonica Lindl. are visited by chiffchaffs, Phylloscopus spp. (La Mantia and R. da Silveira Bueno, pers. comm.), but in order to confirm and quantify their role we should analyze the pollination rate comparing visited vs. non-visited inflorescences.

When mature, the capsular fruits of strelitzias break open to reveal arils whose bright orange color is due to bilirubin, a compound previously known only in animals (Pirone et al. 2009, 2010). This permanent color likely contributes to the long-lasting attraction of avian frugivores (Frost and Frost, 1981; Nichols, 2007) and perhaps to rats. Its appeal for seed dispersers is also due to the high lipid content of the arils (up to $67 \%$ of the dry mass in S. nicolaii according to Frost and Frost 1981). Recent experiments on captive birds (Downs et al. 2015) underlined that some frugivorous birds may have a very high assimilative efficiency, exploiting almost entirely the high lipid content of the arils of S. nicolaii, and to release their seeds in less than half an hour.

\section{CONCLUSIONS}

The bio-ecological traits and the geographic origin of alien plants play a major role in their ability to become invasive out of their original range (Gosper et al. 2010; Marco et al. 2010). Many introduced subtropical and tropical plants escape from backyards many decades after being introduced, and now thrive within seminatural plant communities (Badalamenti et al. 2013) and are able to invade harsh environments (Badalamenti et al. 2018). In order to set up an appropriate management plan for S. nicolaii, more information on its ecology in $S$ Africa should be collected. Furthermore, the speed of local naturalization processes should be monitored, taking into account that in Australia, i.e. under similar Mediterranean-type climatic conditions, S. nicolaii is able to colonize semi-natural environments (Duretto et al. 2017).

Ad hoc investigations, especially focused on ornamental plant nurseries, where individuals of giant blue paradise bird tree may be far more numerous, should be carried out in order to verify if the casual or full naturalization of S. nicolaii already occurred, yet unrecorded, elsewhere in Sicily, S Italy and in the whole Mediterranean area. Any additional information could improve the assessment of the potential behavior of S. nicolaii as a real threat for local plant communities and habitats and help decision-makers in order to plan its eradication if needed (Rejmánek and Pitcairn 2002).
Experimental investigations should be carried out in order to verify to which extent the lack of mechanical soil tillage affects the establishment rate of the seedlings.

It could be interesting to carry out more systematic studies in order to verify which is (or are) the main vectors of pollination and dispersal. A cost-effective strategy could be to put a fix color and infrared camera in order to film not only the diurnal but also the nocturnal visitors of the inflorescences.

\section{ACKNOWLEDGEMENTS}

Special thanks to Pedro Díaz Jiménez (Centro de Investigaciones Tropicales, Universidad Veracruzana, Xalapa, Veracruz, Mexico) for providing first-hand information on the current status of $S$. nicolaii in eastern Mexico and to Carlo Di Leo (Milleotto s.r.l., Palermo) for helping to draw Figure 1. We are grateful to Tommaso La Mantia, Rafael S. Bueno da Silveira (SAAF, University of Palermo) and Bruno Massa for sharing their opinions on the role of frugivorous birds in the dispersal and colonization of introduced plants in the cultivated and abandoned orchards of the Plain of Palermo. Fruitful discussion with Fabio Mondello, Messina, was much appreciated, too. We also wish to thank the anonymous reviewer, whose remarks and suggestions improved the quality of the manuscript.

\section{REFERENCES}

Archer C, 2003. Strelitziaceae. In: Germishuizen G, Meyer NL. (eds.), 'Plants of southern Africa: an annotated checklist'. Kirstenbosch: Strelitzia National Botanical Institute of South Africa; p. 1106.Argent G., 2011. Strelitzia. In: Cullen J, Knees SG, Cubey S. (eds.), 'The European Garden Flora Vol. 1 (Alismataceae to Orchidaceae)', Cambridge (UK): Cambridge University Press, p. 420.

Badalamenti E, Cusimano D, La Mantia T, Pasta S. 2013. The recent spread of the invasive woody alien plant, Melia azedarach L. (Meliaceae), in Sicily. Naturalista sicil., 37: 505-513.

Badalamenti E, Cusimano D, La Mantia T, Pasta S, Romano S, Troia A, Ilardi V. 2018. The ongoing naturalisation of Eucalyptus spp. in the Mediterranean Basin: new threats to native species and habitats. Austral Forestry. 81(4):239-249. https://doi.org/10.1080/00049158.2018.1 533512

Badalamenti E, La Mantia T. 2018. Handroanthus heptaphyllus (Bignoniaceae) in Sicily: a new casual alien to 
Italy and Europe. Fl Medit. 28: 331-338. https://doi. org/10.7320/FlMedit28.331

Baijnath H, McCracken PA. 2019. Strelitzias of the world. A historical and contemporary exploration. Durban: Durban Botanic Gardens Trust, Jacana Publishers, $300 \mathrm{pp}$.

Buscalioni L, Trinchieri G. 1906. Sui movimenti della spata della Strelitzia augusta Thunb. Malpighia. 20: 476-479.

Cecere JC, Matricardi C, Frank B, Imperio S, Spina F, Gargallo G, Barboutis Ch, Boitani L. 2010. Nectar exploitation by songbirds at Mediterranean stopover sites. Ardeola. 57(1): 143-157.

Cron GV, Pirone C, Bartlett M, Kress WJ, Specht C. 2012. Phylogenetic relationships and evolution in the Strelitziaceae (Zingiberales). Systematic Botany. 37(3): 606-619. https://doi.org/10.1600/036364412X648562

Cronk Q, Ojeda I. 2008. Bird-pollinated flowers in an evolutionary and molecular context. J Exp Bot. 59(4): 715-727. https://doi.org/10.1093/jxb/ern009

Da Silva LP, Ramos JA, Olesen JM, Traveset A, Heleno RH. 2014. Flower visitation by birds in Europe. Oikos. 123: 1377-1383. https://doi.org/10.1111/ oik.01347

Downs CT, Shuttleworth A, Wilson A-L. 2015. Assimilation efficiency of the Red-winged Starling Onychognathus morio fed Strelitzia nicolai arils. J Ornithol. 156(1): 323-326. https://doi.org/10.1007/s10336-0141111-3

Duretto MF, McCune S, Luxton R, Milne D. 2017. Strelitzia nicolai (Strelitziaceae): a new species, genus and family weed record for New South Wales. Telopea. 20: 1-3. https://doi.org/10.7751/telopea11022

Dyer RA. 1945. The Flowering Plants of Africa. Pretoria: Van Schaik LTD.

Fiorello A, Speciale M, Lo Verde G, Massa B, 2015. Strelitzia nicolaii (Strelitziaceae), new host plant for Rhynchophorus ferrugineus (Coleoptera Curculionidae) in Sicily. Naturalista sicil. s. 4, 39(2): 435-438.

Frost SK, Frost PGH. 1981. Sunbird pollination of Strelitzia nicolai. Oecologia. 49: 379-384. https://doi. org/10.1007/BF00347603

Galasso G, Conti F, Peruzzi L, Ardenghi NMG, Banfi E, Celesti-Grapow L, Albano A, Alessandrini A, Bacchetta G, Ballelli S, et al. 2018. An updated checklist of the vascular flora alien to Italy. Plant Biosystems 152(3): 556-592. https://doi.org/10.1080/11263504.2 018.1441197

Goldblatt P, Manning J. 2000. Strelitziaceae. in Du Plessis E and Germishuizen G. (eds.), 'Cape plants: A conspectus of the Cape flora of South Africa'. Kirstenbosch: National Botanical Institute of South
Africa; p. 218-219. https://doi.org/10.1046/j.1466822X.2001.00124.X

Gosper CR, Stansbury CD, Vivian Smith G. 2010. Seed dispersal of fleshy fruited invasive plants by birds: contributing factors and management options. Diversity and Distrib. 11(6): 549-558. https://doi.org/ 10.1111/j.1366-9516.2005.00195.x

Lo Valvo M, Massa B, La Mantia T. 1985. Bird population of Palermo's urban and suburban areas. Ital J Zool. 52: 347-354. DOI: 10.1080/11250008509440538

Manetti G. 1845. Catalogi plantarum Caesarei Regii Horti prope Modiciam supplementum secundum ad annum 1. Mediolani: Imp. Regiis Typis: p.24

Marco A, Lavergne S, Dutoit Th, Bertaudiere-Montes V. 2010. From the backyard to the backcountry: how ecological and biological traits explain the escape of garden plants into Mediterranean old fields. Biol. Invasions. 12: 761-779. DOI: 10.1007/s10530-009-9479-3

Merino S, Nogueiras I. 2003. Loquat Eriobotrya japonica as a winter nectar source for birds in central Spain. Ardeola. 50: 265-267.

Moore HE, Hyypio PA. 1970. Some comments on Strelitzia (Strelitziaceae). Baileya. 17: 64-74.

Nichols G. 2007. Natal wild banana Strelitzia nicolai. [accessed 2019 may 30] http://birdinfo.co.za/botanical/fruit/29_strelitzia_nicolai.htm.

Ostinelli V. 1910. Villa Trabia - Terre rosse, Palermo. Descrizione delle piante coltivate nella villa delle LL. EE. il Principe e la Principessa di Trabia e di Butera dal 1882 al 1910. Palermo: Tip. Priulla, p. 94.

Pasta S, Ardenghi NMG, Badalamenti E, La Mantia T, Livreri Console S, Parolo G. 2017. The alien vascular flora of Linosa (Pelagie Islands, Strait of Sicily): update and management proposals. Willdenowia. 47(2): 135-144. https://doi.org/10.3372/wi.47.47205

Pasta S, Badalamenti E, La Mantia T. 2012. Acacia cyclops A. Cunn. ex G. Don (fam. Fabaceae) in Italy: preliminary notes on first naturalization cases. Anales Jard Bot Madrid. 69(2): 193-200. DOI: 10.3989/ajbm.2314

Pasta S, Badalamenti E, Sala G, La Mantia T. 2016. Nicodemia madagascariensis (Lam.) R. Parker (fam. Scrophulariaceae), a casual alien plant new to Italy. Webbia. 71(1): 155-162. https://doi.org/10.1080/00837792 .2016 .1160662

Pasta S, La Mantia T, Badalamenti E. 2014. A casual alien new to Mediterranean Europe: Ceiba speciosa (A. St.Hil.) Ravenna (Malvaceae) in the suburban area of Palermo (NW Sicily, Italy). Anales Jard Bot Madrid. 71(2): e010. https://doi.org/10.3989/ajbm.2387

Pirone C, Johnson JV, Quirke JME, Priestap HA, Lee D. 2010. The animal pigment bilirubin identified in Strelitzia reginae, the bird of paradise flower. HortSci- 
ence. 45(9): 1411-1415. https://doi.org/10.21273/ HORTSCI.45.9.1411

Pirone C, Quirke JME, Priestap HA, Lee DW. 2009. Animal pigment bilirubin discovered in plants. J Am Chem Soc. 131(8): 2830-2830. https://doi. org $/ 10.1021 / \mathrm{ja} 809065 \mathrm{~g}$

Raimondo FM, Domina G. 2007. Two new Mimosaceae naturalized in Italy. Flora Mediterranea. 17: 209-216. http://www1.unipa.it/herbmed/flora/17-209.pdf

Raimondo FM, Fici S. 1991. Nuovi reperti per la flora esotica della Sicilia. Naturalista Sicil. s. 4, 15(3-4): 155-160.

Regel (von) EA, Körnicke FA. 1858. 1. Originalabhandlungen. 1) Abgebildete Pflanzen. a) Strelitzia Nicolai Rgl. \& Körn. In: Regel E. (ed.), Gartenflora - Allgemeine Monatschrift für deutsche, russische und schweizerische Garden- und Blumenkunde, vol. 7. Erlangen: Verlag von Ferdinand Enke, 265-267, plate 235.

Rejmánek M, Pitcairn MJ. 2002. When is eradication of exotic plant pests a realistic goal? In: Veitch C.R., Clout M.N. (eds.), 'Turning the Tide: The Eradication of Invasive Species'. IUCN, Gland, Switzerland and Cambridge, UK, pp. 249-253. http://www.issg.org/ database/species/reference_files/onoaca/Rejmanek.pdf

Speciale M, Domina G. 2016. On the real identity of the Strelitzia cultivated in Sicily's historic gardens. Webbia 71(2): 1-3. DOI: 10.1080/00837792.2016.1191180

Tenore M. 1845. Catalogo delle piante che si coltivano nel R. Orto Botanico di Napoli. Napoli: Tip.[ografia] dell'Aquila.

Todaro A. 1885. Index seminum Horti Regii Botanici Panormitani an.[no] MDCCCLXXXIV qua pro mutua commutatione offeruntur. Palermo: publisher unknown.Turland NJ, Wiersema JH, Barrie FR, Greuter W, Hawksworth DL, Herendeen PS, Knapp S., Kusber W-H, Li D-Z, Marhold K, May TW, McNeill J, Monro AM, Prado J, Price MJ, Smith GF. (eds.) 2018. International Code of Nomenclature for algae, fungi, and plants (Shenzhen Code) adopted by the Nineteenth International Botanical Congress (Shenzhen, China, July 2017). Regnum Vegetabile. 159. Glashütten: Koeltz Botanical Books. https://doi. org/10.12705/Code. 2018

van der Venter HA, Small JGC, Robbertse PJ. 1975. Notes on the distribution and comparative leaf morphology of the acaulescent species of Strelitzia Aiton. J S Afr Bot. 41(1): 1-16.

Villari R, Zaccone R. 1999. Paraserianthes lophantha (Willd.) J. Nielsen (Mimosaceae) a new alien species naturalised to Sicily. Flora Mediterranea. 9:287-290. https://www.herbmedit.org/flora/9-287.pdf
Wright CH. 1913. Strelitzia Aiton. In: Thiselton-Dyer WT. (ed.), 'Flora Capensis, being a systematic description of the plants of the Cape Colony, Caffraria, \& Port Natal (and neighbouring territories) by various botanists'. Vol. 5, Section 3 (Hydrocharideae to Scitamineae). London: Lovell, Reeve and Co. LTD; p. 316-319.

Yamburov MS, Astafurova TP, Zharnakhova EY, Romanova SB, Smolina VM, Khotskova LV. 2016. Reproductive biology of Strelitzia nicolai and Strelitzia reginae in the conditions of a greenhouse. RJPBCS. 7(2): 309-316. 